Advance directives to protect embryos?

\section{Advance directives to protect embryos? K Devolder}

\section{The continuing debate about the use of human embryonic stem cell research}

$\mathrm{T}$ here is a growing consensus among scientists worldwide that embryonic stem (HES) cell research will lead to the development of therapies for common diseases or conditions that affect millions of people, including neurological disease or injury, diabetes, and myocardial infarction. HES cells are also valuable tools in understanding early human developmental processes, cell division and differentiation mechanisms, drug discovery and toxicity testing, and for developing models of human diseases. At the same time many individuals profess to be outraged by the prospect of using human embryos for research and therapeutic purposes and some countries or states have declared such research to be unethical and have banned it. Many people also think it would be immoral to benefit from what they consider to be evil.

Obviously all those who think HES cell research is immoral will wish to ensure not only that no HES cell therapies are developed but that they will not openly or inadvertently benefit from such therapies when they can avoid it. I have accordingly designed the following Advance Directive and here offer it as a service to all those offended by therapeutic and research use of human embryos.

The design of this advance directive to protect embryos highlights an important point that is often overlooked, namely that those who object to HES cell research as unethical and block such research are committed in consistency to the rejection of any benefits or therapies, which may flow from such research. It is questionable whether these people will fully accept this consequence of opposition to HES cell research, and whether this rejection of HES cell research will be practically possible. (Once stem cell therapies have been developed and stem cell research is conducted worldwide it will be very difficult, if not impossible, for practicing physicians to know whether a drug or therapy was or was not developed through HES cell research).

We, and especially policymakers, should keep in mind that very often there is a significant difference between what people say that they believe-that is their professed beliefs, and their actual beliefs revealed by their actions. It does not follow from the fact that people claim that embryos should be protected as if they are persons, that those same individuals will follow through and do everything necessary to ensure that in fact this protection is implemented. In most countries with restrictive legislation on the use of embryos, intrauterine devices, and the "morning after" pill, abortion without medical indication and IVF are generally accepted practices. In all these practices embryos are created and sacrificed for purposes regarded as important and beneficial. Likewise, it is to be expected that if therapies were to be proven for serious illnesses, using HES cells, many people objecting to HES cell research now will not refuse such treatments when they or their loved ones are suffering or dying from a disease for which no other treatment is available. The same can be expected at the level of policy. Will societies that continue to ban or severely restrict HES cell research deny any such treatments to their citizens? This is very unlikely. Of course there will be some individuals who will refuse treatments based on embryo research or products derived from embryos. Just as there are people who, based on their deeply held beliefs, refuse euthanasia while suffering terribly from a terminally illness, and women who refuse to undergo abortion, which would save their own life, to protect the life of their foetus (like Gianna Molla who, while she was pregnant, was diagnosed with a large cyst in her womb, which required surgery and abortion of the fetus. She refused abortion and the child was born healthy, but Gianna died 7 days later. She is now regarded as the martyr and patroness of pro-life and anti-abortion movements).

Here we come to a second reason for designing this advance directive. In a democracy it is not the opinion of the majority alone that determines public policy and regulations, nor should minorities close all the options down for their fellow citizens. The core values in a democracy are freedom and tolerance. As pointed out before, it is to be expected that only a significant minority will actually bring their professed beliefs into practice. When such beliefs are so at odds with self interest and the public good, why would such a minority have the right to block all the options for their fellow citizens? There is no agreement about what moral status to accord to an embryo, and there never will be. Looking for consensus or complex compromises that satisfy neither of the moral positions requires considerable effort and slows down important life saving research. It is time to look for better ways of dealing with the vested interests and entrenched positions in HES cell research, and we should do this in accordance with democratic values, that is, whilst maintaining a maximum degree of choice for citizens.

Respect for minority views can be shown by not imposing choices on them which they consider ethically unacceptable. If people who accord very high value to embryos refuse to benefit from the results of HES cell research, they should have the possibility to do so. But tolerance should not go in one direction only. Options open to some citizens should not be constrained because of deeply held, often religiously based views of others. These minorities should also tolerate the views and wishes of all their fellow citizens who want to have their lives and the lives of their loved ones saved with treatments based on HES cell research or products derived from embryos. However, the problem goes beyond the issue of minority versus majority. Freedom of research is one of the most important rights and moral values in a democracy. It is not an absolute value and can be restrained by other important values such as the safety and respect for research participants and patients. However, in the context of HES cell research, the application of the principle depends greatly on the moral status of the embryo. A justification primarily based on a contested value is insufficient to restrict freedom of research to such a considerable extent.

The way forward in the stem cell debate and, accordingly, stem cell policymaking is to recognise that most people accord a relative moral status to the human embryo and are prepared to accept the creation and sacrifice of embryos for purposes considered as very important, such as life-saving therapies. Most people accord high value to embryos when these are included in a parental project, that is, when people create embryos to start a family, but in most cases (in IVF treatments), this value decreases when the family is completed and the embryos are "left-over". 
Those who don't share this viewpoint should, to the extent possible, have the choice not to benefit from HES cell therapies and they should have the freedom to defend their case-for example, by proving that there are equally effective alternatives that do not require the use of embryos. Stem cell therapies will surely be developed in the not too distant future. Focusing on a minority view on the moral status of embryos may crystallise both the issues and the sincerity of the participants in this crucial contemporary debate. We risk neglecting other issues that may be far more important to most citizens, including their safety and privacy, and their access to life-saving drugs and therapies. If we really do care about human lives, then we should not continue to be hostages of a particular viewpoint on the moral status of the embryo, but we should start to focus on these other issues. The proposed advance directive is meant to dramatise the consequences of consistently holding a particular moral view and to stimulate discussion about how the debate should proceed.

\section{ACKNOWLEDGEMENTS}

I want to express my gratitude to the Voluntary Euthanasia Society (VES) in the
UK and especially to Deborah Annetts, who was so kind as to let me adapt their living will for the purpose of this paper. The VES have no responsibility whatsoever for the use I have made of it here. I wished, however, to use a standard and well accepted and well thought out format for advance directives, hence my choice of that developed by the VES. I am also grateful to John Harris for comments on an earlier draft.

J Med Ethics 2005;31:497-498. doi: 10.1136/jme.2005.013607

Correspondence to: K Devolder, Centre for Environmental Philosophy and Moral Sciences, Ghent University, Blandijnberg 2, 9000 Ghent, Belgium; katrien.devolder@ugent.be

\section{Call for papers}

The Journal of Medical Ethics is planning to publish a number of thematic issues and invites submissions of original or short papers on the following topics:

Deadline 15 December 2005

Public Health Ethics

Ethical issues is obstetrics and gynaecology

Multidisciplinary research in medical ethics

\section{Deadline 15 June 2006}

Equity and justice in health care

Ethical issues in oncology and palliative care

Teaching ethics to health care students and professionals

If you would like to discuss a possible submission please e-mail Søren Holm at holms@cardiff.ac.uk with your idea. Prior discussion with the editor is not obligatory.

Please state in your submission letter that you would like the paper considered for a thematic issue. 